\title{
IMPLEMENTASI PEMBELAJARAN KOLABORATIF MENGGUNAKAN BREAKOUT ROOM ZOOM MEETING PADA PEMBELAJARAN JARAK JAUH
}

\author{
FARAH FAUZIAH \\ SMAN 82 Jakarta \\ Email : fauziahfarah@gmail.com
}

\begin{abstract}
ABSTRAK
Penelitian ini dilakukan untuk mengetahui pengaruh strategi pembelajaran Kolaboratif dalam belajar online pada saat pembelajaran jarak jauh. Metode yang digunakan adalah eksperimen dengan desain penelitian pretest-posttest. Media Online yang digunakan adalah aplikasi zoom meeting. Terdapat dua kelompok yaitu kelompok eksperimen dan kelompok kontrol yang dipilih secara acak serta telah dilakukan uji normalitas dan uji homogenitas. Kelompok eksperimen adalah kelompok yang diberikan strategi pembelajaran kolaboratif, sedangkan kelompok kontrol menggunakan metode konvensional. Teknik analisis data yang digunakan adalah teknik tes. Berdasarkan hasil penelitian diperoleh N-gain score kelompok eksperimen (kolaboratif) adalah 63,6904 atau 63,7\% dan masuk dalam kategori cukup efektif. Rata-rata gain ternormalisasi ( $\mathrm{N}$-gain) hasil belajar peserta didik kelompok eksperimen adalah 0,63 yang termasuk kategori sedang. Artinya penerapan strategi pembelajaran kolaboratif cukup dapat meningkatkan hasil belajar peserta didik pada pokok bahasan Ide dan Peluang Usaha di kelas X SMAN 82 Jakarta.
\end{abstract}

Kata Kunci: Kolaboratif, Belajar Online, Zoom Meeting

\section{ABSTRACT}

This study was conducted to determine the effect of Collaborative learning strategies in online learning during distance learning. The method used is an experiment with a pretest-posttest research design. The online media used is the zoom meeting application. There are two groups, namely the experimental group and the control group which were selected randomly and have been tested for normality and homogeneity tests. The experimental group is the group that is given a collaborative learning strategy, while the control group uses the conventional method. The data analysis technique used is a test technique. Based on the results of the study, the Ngain score of the experimental group (collaborative) was 63.6904 or $63.7 \%$ and was categorized as quite effective. The average normalized gain ( $\mathrm{N}$-gain) of the experimental group students' learning outcomes was 0.63 which was included in the medium category. This means that the application of collaborative learning strategies is sufficient to improve student learning outcomes on the subject of Ideas and Business Opportunities in class X SMAN 82 Jakarta.

Keywords: Collaborative, Online Learning, Zoom Meeting

\section{PENDAHULUAN}

Belajar Online (Online learning) mulai menjadi trend di era digital serta dapat dijadikan alternatif pembelajaran dalam banyak situasi, seperti yang terjadi di seluruh dunia saat pandemi covid-19. Indonesia merupakan salah satu negara yang terdampak pandemi covid-19. Dalam bidang pendidikan, pemerintah memberlakukan kebijakan belajar dari rumah dengan fasilitas internet (belajar online) atau yang lebih dikenal dengan pembelajaran jarak jauh untuk mengurangi berkumpulnya masa pada suatu tempat. Hal ini dimaksudkan untuk memutus penyebaran virus Covid-19. Pemberlakuan physical dan social distancing menyebabkan kegiatan belajar mengajar tidak dapat lagi dilakukan di dalam kelas.

Pembelajaran jarak jauh yang dilakukan secara online membuat banyak sekali perubahan, baik dari segi metode pembelajaran maupun dari segi penilaian. Semua institusi pendidikan melakukan pembelajaran secara online (daring) sesuai kemampuan. Belajar online (daring) dapat dilakukan dengan menggunakan teknologi digital seperti Whatsapp, google classroom, google meet, zoom meeting, edmodo, schology dan lainnya. 
Pesatnya perkembangan teknologi informasi dan komunikasi (TIK), ditambah dengan kondisi pandemi yang mengharuskan pembelajaran di rumah membuat pembelajaran kolaboratif sangat mungkin dilakukan saat ini. Kolaborasi sebenarnya merupakan kebutuhan manusia, sehingga manusia sebagai makhluk sosial tentunya selalu berhubungan dengan orang lain, bekerja sama dan saling membantu. Kolaborasi juga merupakan keharusan dalam kegiatan pembelajaran. Dalam kegiatan pembelajaran tradisional, kolaborasi biasanya terjadi antara siswa atau guru dari sekolah atau kelas yang sama. Namun dengan tersedianya jaringan komunikasi internet, kerjasama antar sekolah, antar daerah, bahkan lintas batas negara sangat dimungkinkan. Salah satu pelajaran besar di balik bencana pandemi COVID-19 di dunia pendidikan adalah kita telah "dipaksa" menggunakan TIK untuk pembelajaran. Pembelajaran berbasis TIK di masa pandemi menunjukkan dinamika yang luar biasa. Di satu sisi, ini merupakan berkah, pencapaian yang luar biasa dibandingkan dengan upaya yang telah dilakukan selama bertahun-tahun untuk mensosialisasikan pemanfaatan TIK.

Salah satu pemanfaatan media online berbasis TIK yang banyak digunakan pada saat pembelajaran jarak jauh adalah zoom meeting. Zoom Meeting adalah layanan perangkat komunikasi video telepon yang dapat digunakan untuk aktivitas online atau daring dengan perangkat Open Source Software (OSS). Perangkat lunak Zoom diluncurkan pada tahun 2013 dan terus berkembang serta menjadi sangat terkenal pada saat pandemi covid-19 yang terjadi diseluruh dunia. Zoom merupakan salah satu aplikasi yang sangat membantu dalam belajar online terutama pada saat pandemi covid-19. Hal ini karena zoom dapat menghubungkan para pengguna tanpa harus bertemu secara langsung. Zoom bisa diakses menggunakan PC maupun smartphone dengan melakukan install aplikasi.

Zoom dapat diakses dengan cara gratis (basic) ataupun berbayar (pro). Zoom basic mengizinkan pengguna melakukan video conference dengan waktu maksimal 40 menit untuk setiap pertemuan dengan jumlah peserta hingga mencapai 100 orang. Fasilitas yang didapatkan yaitu kualitas suara dan gambar HD, screen-sharing, akses ke virtual background, membuat jadwal hingga merekam keseluruhan meeting, membagi peserta dalam ruangan - ruangan kecil dengan fitur Breakout Rooms.

Breakout Room merupakan fitur yang sangat dibutuhkan jika ingin membuat diskusi kecil per kelompok di dalam meeting. Misal, ketika dalam pembelajaran peserta didik ditugaskan menemukan ide dengan berdiskusi antar peserta didik. Breakout Room sangat membantu menjaga kondusifitas pembelajaran karena peserta didik akan dibagi menjadi beberapa kelompok dan akan berdiskusi (menyalakan audio dan kamera) di room masingmasing. Pendidik dapat menentukan berapa lama durasi breakout yang dibutuhkan. Jika waktu breakout sudah habis, maka seluruh peserta didik akan kembali bergabung ke dalam room meeting utama.

Pandemi covid-19 menyebabkan pembelajaran tidak dapat dilakukan secara tatap muka. Pendidik melakukan berbagai cara agar pembelajaran dapat berlangsung dengan baik. Strategi pembelajaran tidak boleh monoton agar peserta didik tidak merasa bosan. Strategi yang dapat diimplementasikan salah satunya adalah strategi pembelajaran kolaboratif. Ada banyak model pembelajaran kolaboratif, termasuk yang disebutkan oleh Suryani (2010), seperti: 1) pembelajaran kolaboratif, 2) turnamen bermain tim, 3) penelitian kelompok, 4) kontroversi akademik yang konstruktif, 5) proses teka-teki, 6) Siswa kinerja tim, departemen, 7) Pengajaran kompleks, 8) Pengajaran tim yang dipercepat, 9) Struktur pembelajaran kooperatif, 10) Membaca dan komposisi kooperatif terintegrasi. Suryani juga menunjukkan sejumlah manfaat dari penggunaan pembelajaran kolaboratif sebagai berikut: 1) peningkatan kinerja pembelajaran; 2) pemahaman yang lebih dalam; 3) belajar lebih menyenangkan; 4) mengembangkan keterampilan kepemimpinan; 5) meningkatkan sikap positif; 6) meningkatkan harga diri; 7) pembelajaran inklusif; 8) rasa kebersamaan; dan 9) pengembangan keterampilan di masa depan.

Pembelajaran kolaboratif adalah pembelajaran di mana siswa dengan latar belakang dan kemampuan yang berbeda bekerja sama dalam kelompok kecil untuk mencapai tujuan bersama. 
Ada beberapa karakteristik pembelajaran kolaboratif, yaitu: (1) ketergantungan positif, (2) adanya interaksi (tatap muka), (3) tanggung jawab individu dan kelompok, (4) pengembangan keterampilan interpersonal (keterampilan interpersonal). (5) pembentukan kelompok yang heterogen, (6) pertukaran pengetahuan antara guru dan siswa, (7) pembagian wewenang atau peran antara guru dan siswa, dan (8) guru sebagai perantara. Pembelajaran kolaboratif sesuai dengan konstruktivisme. Menurut konstruktivisme, pengetahuan tidak dapat ditransfer dari satu guru ke guru lain, tetapi harus dibangun secara aktif oleh siswa itu sendiri. Siswa membangun pengetahuan mereka dengan menguji ide dan pengalaman mereka sendiri, menerapkannya pada situasi baru, dan mengintegrasikan pengetahuan yang baru.

Melalui pembelajaran kolaboratif, siswa dapat saling mendukung melalui bimbingan intelektual yang memungkinkan mereka untuk mengerjakan tugas yang lebih kompleks. Hal ini akan sulit dicapai jika siswa melakukannya secara individu. Pembelajaran kolaboratif memungkinkan nilai tambah yang besar bagi siswa dan guru. Manfaat ini meliputi; 1) Siswa memiliki pengalaman bekerja tidak hanya dengan teman sekelasnya, tetapi juga dengan siswa lain yang tidak mereka ketahui sebelumnya. 2) Dalam pembelajaran kolaboratif, interaksi antara siswa yang baru bertemu terfokus karena mengikuti program yang direncanakan oleh guru, 3) Kegiatan yang bersifat kolaboratif cenderung menumbuhkan motivasi dan semangat bersaing siswa dalam arti positif. 4) Siswa juga banyak menerima sumber belajar dari guru yang bukan guru di sekolahnya sendiri yang mereka kenal.

Oleh karena itu, dari pemaparan di atas maka penelitian ini berkenaan dengan strategi pembelajaran. Apakah melalui strategi kolaboratif dapat lebih mengaktifkan peserta didik dan pembelajaran menjadi lebih efektif perlu ditindaklanjuti melalui serangkaian kegiatan penelitian.

\section{METODE PENELITIAN}

Penelitian ini dilakukan dengan eksperimen menggunakan metode pretest-posttest dengan memberikan perlakuan pada kelompok eksperimen serta membuat kelompok kontrol untuk pembanding. Kedua kelompok diperlakukan sama dari tujuan dan materi, tetapi berlainan pada strategi pembelajarannya. Pembelajaran Online dilakukan dengan menggunakan aplikasi zoom meeting. Kelompok eksperimen menggunakan metode pembelajaran kolaboratif dengan fitur breakout room. Sedangkan kelompok kontrol menggunakan metode pembelajaran konvensional dengan ceramah.

Pre-test digunakan untuk mengetahui kemampuan awal peserta didik kemudian dianalisa dan diuji kesamaan dua rata-rata. Post-test dilakukan untuk memperoleh nilai sebagai wujud dari prestasi belajar, selanjutnya dianalisa serta diuji, sehingga diketahui perbedaan prestasi belajar antara kelompok eksperimen dan kelompok kontrol.

Tabel 1. Rencana Penelitian

\begin{tabular}{llll}
\hline Kelompok & Pretest & Perlakuan & Posttest \\
\hline Eksperimen & $\mathrm{T}_{1}$ & Kolaboratif & $\mathrm{T}_{2}$ \\
Kontrol & $\mathrm{T}_{1}$ & konvensional & $\mathrm{T}_{2}$ \\
\hline
\end{tabular}

Populasi dalam penelitian ini adalah peserta didik kelas X IPS SMA Negeri 82 Jakarta, kemudian dipilih sampel penelitian dua kelas X IPS. Sample diambil secara acak untuk diberikan perlakuan berjumlah 25 peserta didik. Teknik Cluster random sampling digunakan agar setiap peserta didik memperoleh kesempatan (chance) dipilih menjadi sampel. Instrumen penelitian adalah tes hasil belajar pada ranah kognitif mata pelajaran PKWU pada materi Ide dan Peluang usaha, meliputi ingatan (C1), pemahaman (C2), aplikasi (C3). Bentuk instrumen dalam penelitian ini adalah pilihan ganda (multiple choice test).

Untuk mengetahui peningkatan pembelajaran dapat menggunakan gain ternormalisasi. Berikut adalah rumus gain menurut Meltzer dalam (Adam, 2017): 


$$
\mathrm{N} \text { Gain }=\frac{\text { Skor Posttest }- \text { Skor Pretest }}{\text { skor Ideal }- \text { Skor Pretest }}
$$

Hasil perhitungan diinterpretasikan dengan menggunakan indeks gain $(\mathrm{g})$ menurut Meltzer dalam (Adam, 2017) sebagai berikut:

Tabel 2. Kriteria Gain

\begin{tabular}{ll}
\hline Indeks Gain & Kategori \\
\hline $\mathrm{g}>0,70$ & Tinggi \\
$0,30<\mathrm{g}<0,70$ & Sedang \\
$\mathrm{g} \leq 0,30$ & Rendah \\
\hline
\end{tabular}

Kategori N-Gain pada bentuk persen (\%) dapat dilihat pada tabel di bawah ini

Tabel 3. Kategori N-Gain dalam bentuk persen (\%)

\begin{tabular}{ll}
\hline Presentase $(\%)$ & Tafsiran \\
\hline$<40$ & Tidak Efektif \\
$40-55$ & Kurang Efektif \\
$56-75$ & Cukup Efektif \\
$>76$ & Efektif \\
\hline
\end{tabular}

\section{HASIL DAN PEMBAHASAN}

\section{Hasil}

\section{A. Uji Normalitas (Pre Test dan Post Test)}

Tabel 4. Hasil Uji Normalitas Pre Test

\begin{tabular}{llccc}
\hline \multirow{2}{*}{ Kelompok } & \multicolumn{3}{c}{ Shapiro-Wilk } \\
\cline { 3 - 5 } & Kelompok Eksperimen & 0.943 & 25 & 0.170 \\
\hline Hasil Belajar & Kelompok Kontrol & 0.892 & 25 & 0.012 \\
\hline
\end{tabular}

Tabel 5. Hasil Uji Normalitas Post Test

\begin{tabular}{ccccc}
\hline \multirow{2}{*}{ Kelompok } & \multicolumn{3}{c}{ Shapiro-Wilk } \\
\cline { 3 - 5 } & Kelompok Eksperimen & 0.945 & 25 & 0.195 \\
\hline Hasil Belajar & Kelompok Kontrol & 0.948 & 25 & 0.225 \\
\hline
\end{tabular}

Tabel 4 dan tabel 5 merupakan data nilai pre test dan post test hasil belajar peserta didik. Data nilai pre test dan post test hasil belajar peserta didik digunakan untuk uji prasyarat analisis yaitu uji normalitas dan uji homogenitas. Menurut Singgih Santoso dalam bukunya menguasai statistik menggunakan SPSS 25, data dikatakan berdistribusi normal (simetris) dalam uji shapiro wilk (jumlah data di bawah 50) jika nilai Sig.>0,05. Berdasarkan output uji normalitas pada pre test diketahui nilai Sig. untuk kelompok eksperimen sebesar 0,170 dan nilai Sig. kelompok kontrol sebesar 0,012. Sedangkan pada post test nilai Sig. untuk kelompok eksperimen sebesar 0,195 dan nilai Sig. kelompok kontrol sebesar 0,225. Nilai Sig. untuk kedua kelompok > 0,05, dapat disimpulkan bahwa data hasil belajar peserta didik berdistribusi normal. 


\section{B. Uji Homogenitas (Pre Test dan Post Test)}

Uji homogenitas untuk mengetahui varian populasi sama atau tidak. Kriteria pengujian, jika nilai signifikansi > 0,05 maka dapat dikatakan varian dari dua atau lebih kelompok data adalah sama.

Tabel 6. Hasil Uji Homogenitas Pre Test

\begin{tabular}{cccc}
\hline Levene Statistic & df1 & df2 & Sig. \\
\hline 0.881 & 1 & 48 & 0.353 \\
\hline
\end{tabular}

Tabel 7. Hasil Uji Homogenitas Post Test

\begin{tabular}{cccc}
\hline Levene Statistic & df1 & df2 & Sig. \\
\hline 0.000 & 1 & 48 & 0.997
\end{tabular}

Hasil Uji homogenitas kelompok eksperimen dan kelompok kontrol diperoleh hasil Sig. $0,353(0,353>0,05)$ pada pre test dan $0,997(0,997>0,05)$ pada post test sehingga dapat disimpulkan kedua data tersebut homogen.

\section{Hasil Uji T}

Tabel 8. Hasil Uji N-Gain

\begin{tabular}{|c|c|c|c|c|c|}
\hline NGain_Persen & \multicolumn{3}{|l|}{ Kelompok } & \multirow{2}{*}{$\frac{\text { Statistic }}{63.6904}$} & \multirow{2}{*}{$\frac{\text { Std. Error }}{2.61134}$} \\
\hline & Kelompok & Mean & & & \\
\hline & Eksperimen & 95\%Confidence & Lower & 68.3009 & \\
\hline & & interval & Bound & & \\
\hline & & for Mean & Upper & 69.0800 & \\
\hline & & & Bound & & \\
\hline & & $5 \%$ Trimmed & & 64.1434 & \\
\hline & & Mean & & & \\
\hline & & Median & & 61.5385 & \\
\hline & & Variance & & 170.477 & \\
\hline & & Std. Deviation & & $1.3056 \mathrm{E} 1$ & \\
\hline & & Minimum & & 36.84 & \\
\hline & & Maximum & & 81.08 & \\
\hline & & Range & & 44.24 & \\
\hline & & Interquartile & & 25.51 & \\
\hline & & Range & & & \\
\hline & & Skewness & & -.219 & .464 \\
\hline & & Kurtosis & & -1.125 & .902 \\
\hline & Kelompok & Mean & & 41.6699 & 3.29366 \\
\hline & Kontrol & 95\%Confidence & Lower & 34.8721 & \\
\hline & & interval & Bound & & \\
\hline & & for Mean & & 48.4677 & \\
\hline & & $5 \%$ Trimmed & Upper & 41.9497 & \\
\hline & & Mean & Bound & & \\
\hline & & Median & & 42.8571 & \\
\hline & & Variance & & 271.205 & \\
\hline & & Std. Deviation & & $1.6468 \mathrm{E} 1$ & \\
\hline & & Minimum & & 6.67 & \\
\hline & & Maximum & & 70.00 & \\
\hline & & Range & & 63.33 & \\
\hline
\end{tabular}


Interquartile

24.49

Range

Skewness

$-.118$

.464

Kurtosis

$-.589$ .902

\section{Pembahasan}

Berdasarkan tabel hasil uji N-gain score di atas, menunjukkan bahwa nilai rata-rata $\mathrm{N}-$ gain score kelompok eksperimen (kolaboratif) adalah 63,6904 atau 63,7\% masuk dalam kategori cukup efektif. Dengan nilai N-gain score minimal 36,84\% dan maksimal 81,08\%. Sedangkan rata-rata $\mathrm{N}$-gain score kelompok kontrol (konvensional) adalah 41,6699 atau 41,7\% masuk dalam kategori kurang efektif. Dengan nilai N-gain score minimal 6,67\% dan maksimal $70,00 \%$. Dengan demikian, dapat diambil kesimpulan bahwa penggunaan strategi kolaboratif cukup efektif untuk meningkatkan hasil belajar pada mata pelajaran PKWU materi Ide dan Peluang Usaha peserta didik kelas X SMAN 82 Jakarta Tahun Pelajaran 2021. Sedangkan penggunaan metode konvensional kurang efektif.

\section{KESIMPULAN}

Berdasarkan analisis data pada hasil penelitian dan pembahasan dapat disimpulkan:

1. Penerapan strategi pembelajaran Kolaboratif pada saat pembelajaran jarak jauh dapat meningkatkan hasil belajar peserta didik pada materi pokok Ide dan Peluang Usaha kelas X IPS SMAN 82 Jakarta.

2. Peningkatan hasil belajar peserta didik melalui penerapan strategi pembelajaran Kolaboratif pada materi pokok Ide dan Peluang Usaha kelas X IPS SMAN 82 Jakarta kelompok eksperimen berada pada kategori cukup dengan nilai Gain ternormalisasi (N-Gain) sebesar 0,63 .

\section{DAFTAR PUSTAKA}

Adam, F. (2017). Jurnal Pendidikan Fisika Universitas Muhammadiyah Makassar Peranan Strategi Kolaboratif (Saling Tukar. 5, 37-42).

Ahmad. (2021). Cara Menggunakan Zoom Meeting. https://www.gramedia.com/bestseller/cara-menggunakan-zoom-meeting/ diakses pada 23 Juni 2021

C, B. D., Amelia, A., Hasanah, U., \& Putra, A. M. (n.d.). Analisis Keefektifan Pembelajaran Online di Masa Pandemi Covid-19.

Dimyati dan Mudjiono. (1999). Belajar dan Pembelajaran. Jakarta: PT Rineka Cipta.

Hisyam Zaini, dkk. (2008). Strategi Pembelajaran Aktif. Madani. Yogyakarta.

Frelberg, H.J. and Driscoll, A. (1992). Universial Teaching Strategies. Boston: Allyn \& Bacon Hasanah, dkk. (2020). Analisis Aktivitas Belajar Daring Mahapeserta didik Pada Pandemi COVID-19. Jurnal Pendidikan. Volume 1 No.1.

Hake, R. R. (1998). Interactive-engagement versus traditional methods: A six-thousand-student survey of mechanics test data for introductory physics courses. American journal of Physics, 66(1), 64-74

Perkantoran, A. (2019). Jurnal Informasi dan Komunikasi Administrasi Perkantoran Volume 3, No 1, Februari 2019 Online: http://jurnal.fkip.uns.ac.id/index.php/jikap. 3(1), 1-14.

Sofyana, L., \& Rozaq, A. (2019). PGRI MADIUN. 8.

Silberman, Mel. (2007). Active Learning 101 Strategi Pembelajaran Aktif. Jogyakarta: Pustaka Insan Madani.

Suryani, Nunuk. (2010). implementasi model pembelajaran kolaboratif untuk meningkatkan ketrampilan sosial siswa.

Hake, Richard R. (1999). Analyzing change/gain scores. Indiana University. Woodland. Hills. $\begin{array}{lllll}\text { Diakses } & \text { pada } & 4 & \text { Juli } & 2021\end{array}$ http://www.physics.indiana.edu/ sdi/Analyzing Change-Gain.pdf. 
EDUTECH : Jurnal Inovasi Pendidikan Berbantuan Teknologi

Vol. 1 No. 3 November 2021, e-ISSN : 2797-0140 | p-ISSN : 2797-0590

Rahardjo, Sahid. (2019). Cara menghitung n-gain score. https://www.spssindonesia.com/2019/04/cara-menghitung-n-gain-score-spss.html, diakses pada 2 Juli 2021.

Supardi. (2013). Sekolah Efektif Konsep Dasar dan Praktiknya. PT Raja Grafindo Persada, Jakarta.

Yolanda, aulea dymas, Copriandy, J., \& Haryati, S. (n.d.). Kolaboratif Pada Pokok Bahasan Struktur Atom Kolaboratif Pada Pokok Bahasan Struktur Atom. 1-7. https://media.neliti.com/media/publications/206176-penerapan-strategipembelajaran-active-k.pdf 